\title{
Epidemiology survey of infectious diseases in North Korean travelers, 2015-2017
}

\author{
Pengyu Han ${ }^{1,2}$, Yanxia Teng ${ }^{3}$, Xiuxin $\mathrm{Bi}^{4}$, Jinge $\mathrm{Li}^{2}$ and Dianxing Sun ${ }^{1 *}$
}

\begin{abstract}
Background: Up until now, there are limited studies available on the epidemiology of infectious diseases in Democratic People's Republic of Korea (DPRK, North Korea). However, different types of infectious diseases have been found in North Korean travelers at Dandong port. Entry surveillance data of those North Korean travelers may provide some insight into the probable epidemiology of some infectious diseases in DPRK.

Methods: We actively analyzed the medical test result of North Korean travelers entering China through Dandong port. Detection of hepatitis B virus (HBV), tuberculosis (TB), syphilis and malaria was made by specific laboratory tests according to the national technical guidelines. Infectious diseases surveillance data for 2015-17 was analyzed and compared among subgroups.

Results: Between Jan 1, 2014, and Dec 31, 2016, 557 cases of infectious diseases were identified among 18,494 North Korean travelers, HBV active infection (466 cases), active TB infection (33 cases), current active syphilis infection (57) cases, Plasmodium falciparum (P.falciparum) malaria infection (1 case). The incidence of HBV, TB and syphilis in North Korean travelers was high. Incidence of TB increased from $11.7256(1 / 10,000)$ in 2015 to $28.2738(1 /$ $10,000)$ in 2017. HBV immunization rate in in North Korean travelers was relatively high in 0-10 age group.

Conclusion: This report is the first to characterize the profile of infectious diseases among arriving North Korean travelers in mainland China. Our findings suggest high incidence of HBV, TB and syphilis among North Korean travelers. The screening for TB in North Korean workers should be strengthened in order to prevent infections imported into China.
\end{abstract}

Keywords: DPRK, Hepatitis B virus, Tuberculosis, Syphilis, Malaria, Port

\section{Background}

DPRK rarely reports its domestic health status to the international world. Up until now, only limited researches were conducted to investigate the prevalence of infectious disease in DPRK. However, researches from the World Health Organization (WHO) and other international groups show that TB, HBV, malaria and other communicable diseases are still rampant in DPRK [1-4]. It is estimated that there is a high prevalence of HBV infection in DPRK due to poor vaccination status and lack of antiviral treatment [5]. In 2003, a filed survey conducted by WHO showed that the prevalence of HBV was $4.5 \%$ in DPRK, while other studies showed a higher

\footnotetext{
* Correspondence: 799103260@qq.com

'Department of Infectious Diseases, Bethune International Peace Hospital, NO.398, Zhongshanxi Road, Shijiazhuang, Hebei Prov 050082, People's Republic of China

Full list of author information is available at the end of the article
}

prevalence of $20 \%$ in some rural areas [5-7]. Data from WHO indicates the prevalence of TB in DPRK was 399/ 100,000 in 2011, 345/100,000 in 2012 and 442/100,000 in 2014 [8-11]. In 2016, DPRK launched its first national field TB prevalence survey which showed a prevalence of 634/100,000 [12]. With the help of global founds, North Korea has developed their own TB treatment program [13], but exactly how these found were used remains largely unknown [14]. DPKR has suffered from Plasmodium vivax (P.vivax) malaria epidemic several times in history [15]. Successful experience of using primaquine preventive treatment (MPPT) to treat malaria in China has encouraged DPRK to start implementing their own MPPT program which significantly reduced the prevalence of P.vivax malaria in DPRK. As a result, reported cases of malaria infection in DPRK dropped from 296,540 in 2001 to 5113 in 2016 [15].

(c) The Author(s). 2019 Open Access This article is distributed under the terms of the Creative Commons Attribution 4.0 International License (http://creativecommons.org/licenses/by/4.0/), which permits unrestricted use, distribution, and reproduction in any medium, provided you give appropriate credit to the original author(s) and the source, provide a link to the Creative Commons license, and indicate if changes were made. The Creative Commons Public Domain Dedication waiver (http://creativecommons.org/publicdomain/zero/1.0/) applies to the data made available in this article, unless otherwise stated. 
Dandong is the largest border city in China and Dandong port is the largest land port connecting China and DPRK. Data from the former China Inspection and Quarantine Bureau (CIQ) suggests that there are about 50,000 North Korean travelers entering China through Dandong port each year. The objective of the present study was to investigate the incidence of hepatitis, syphilis, malaria and tuberculosis in those North Korean travelers.

\section{Methods}

According to core capacity requirements for surveillance and response in WHO's International Health Regulations and the Frontier Health and Quarantine Law of China, all foreigners intend to work or live in China must undergo medical examinations which include tests for HBV, Syphilis and tuberculosis $[16,17]$. As for travelers who have been to epidemic areas, test for related diseases such as malaria and yellow fever are advised. In routine examination, internal medicine check, electrocardiogram examination, abdominal B-ultrasound and chest X-ray examination were performed. In Laboratory tests, Elisa and fluorescence quantitative PCR, toluidine red unheated serum test (TRUST) and treponema pallidum antibody agglutination test (TPPA) were performed at Liaoning International Travel Healthcare Center (ITHC); Sputum smear and mycobacterium tuberculosis culture were performed to detect tuberculosis at Shenyang International Travel Healthcare Center.Epidemiology filed survey was conducted in a Chinese factory where 5 cases of imported pulmonary TB were found. Factory workers were asked to complete a questionnaire with questions about demographics, pulmonary TB awareness and TB exposure history. A follow-up investigation of the sanitary measures adopted in the factory was performed.

\section{Results}

Between Jan 1, 2015, and Dec 31, 2017, 18,494 North Korean nationals were examined for infectious diseases, $4521(24.45 \%)$ were male and 13,973 (75.55\%) were female; 557 cases of infectious diseases were detected in participants: active HBV infection (466 cases), current active syphilis infection (57 cases), active TB infection (33 cases), P.vivax malaria infection (1 case). Participants were divided into 7 age groups, 20-30 age group had the highest incidence of infectious disease, 134.0975(1/10,000) (248 cases).

The number of cases imported varied greatly by reasons for travel, 16,074 (86.91\%) were labor workers, 1354(7.32\%) were on business trip; 544 (2.94\%) were foreign marriages; $473(2.56 \%)$ were students; incidence of active HBV active infection was highest in business trip group $(420.9749,1 / 10,000)$ followed by Marriage $(257.3529,1 / 10,000)$ and export labor workers (243.8721, 1/10,000); incidence of syphilis and TB infection were highest in labor workers; incidence of syphilis and TB infection in North Korean nationals had increased from
2015 to 2017; incidence of active HBV infection was highest in 2016 and dropped in 2017 (Table 1).

HBV infection and immunization status were analyzed in different age groups, 0-10 age group had the highest immunization rate (46.67\%), 51-60 age group had the highest HBV active infection rate (5.91\%), 41-60 age group had the highest $\mathrm{HBV}$ past infection rate $(0.92 \%)$, 11-20 age group had the highest $\mathrm{HBV}$ negative rate (98.71\%) (Table 2).

Gender and age distribution of syphilis were described, 42 cases with current activity of syphilis infection were female and 12 cases were male; in female group, incidence of past syphilis infection was highest in 41-50 age group $(145.2785,1 / 10,000)$ followed by $31-40$ age group (49.2368, 1/10,000), incidence of current active syphilis was highest in 31-40 age group $(64.0079,1 / 10,000)$ followed by $41-50$ age group $(60.5327,1 / 10,000)$ and $21-30$ age group $(27.2997,1 / 10,000)$; in male group, incidence of past syphilis infection was highest in 41-50 age group $(32.0307,1 / 10,000)$ followed by $31-40$ age group $(31.1042,1 / 10,000)$, incidence of current active syphilis was highest in 31-40 age group (108.8647, 1/ $10,000)$ followed by $21-30$ age group $(59.3472,1 / 10,000)$ and $41-50$ age group $(12.8123,1 / 10,000)$ (Table 3$)$.

In Dec, 2017, 5 cases of active pulmonary TB infection were diagnosed in a group of North Korean female workers entering China through Dandong port. All these workers were destined to work in a garment processing factory in Dandong, 5 confirmed TB cases were young females aged 20-30. Questionnaires were sent to patients' co-workers and factory managers, only 58 valid questionnaires were collected, 42 were signed by DPRK workers and 16 were signed by factory managers. The questionnaires showed that only $9(21.43 \%)$ workers knew the basic knowledge about TB is and only 3 (9.52\%) North Korean workers knew how to prevent TB from transmitting. Those 5 workers were sent back to North Korea right after the diagnosis. Sanitation measures such as disinfection spry and propaganda of TB awareness were performed in this factory by local Central Disease Control (CDC) to prevent further TB transmission.

In Sep, 2015, 1 case of P.falciparum malaria infection was found in a North Korean worker who took an international train going back to DPRK through Dandong port. Epidemiology survey revealed that this patient worked in Congo for 1 year and had malaria patient exposure history during his stay in Congo. Unfortunately, the patient went back to DPRK before the test result came out.

\section{Discussion}

To our knowledge, ours is the first study of infectious diseases among North Korean travelers arriving in mainland China. Our findings, which are based on surveillance data, are helpful for providing some insight into the probable 
Table 1 Demography distribution of infectious diseases in North Korean travelers

\begin{tabular}{|c|c|c|c|c|c|c|c|}
\hline \multirow[t]{2}{*}{ Subject } & \multirow{2}{*}{$\begin{array}{l}\text { Overall } \\
\text { N (\%) }\end{array}$} & \multicolumn{2}{|c|}{ HBV active infection } & \multicolumn{2}{|c|}{ Current active syphilis } & \multicolumn{2}{|l|}{$\mathrm{TB}$} \\
\hline & & Case & Prevalence $(1 / 10,000)$ & Case & Prevalence $(1 / 10,000)$ & Case & Prevalence $(1 / 10,000)$ \\
\hline \multicolumn{8}{|l|}{ Gender } \\
\hline Male & $4521(24.45)$ & 264 & 583.9416 & 15 & 33.1785 & 0 & 0.0000 \\
\hline Female & $13,973(75.55)$ & 202 & 144.5645 & 42 & 30.0580 & 33 & 23.6170 \\
\hline \multicolumn{8}{|l|}{ Age } \\
\hline $0-10$ & $15(0.08)$ & 0 & 0.0000 & 0 & 0.0000 & 0 & 0.0000 \\
\hline $11-20$ & 2937 (15.88) & 18 & 60.9756 & 1 & 3.3875 & 2 & 6.7751 \\
\hline $21-30$ & $9436(51.02)$ & 195 & 206.6554 & 25 & 26.4943 & 26 & 27.5540 \\
\hline $31-40$ & $2674(14.46)$ & 94 & 351.5333 & 20 & 74.7943 & 3 & 11.2191 \\
\hline $41-50$ & $2387(12.91)$ & 101 & 423.1253 & 7 & 29.3255 & 2 & 8.3787 \\
\hline $51-60$ & $982(5.31)$ & 58 & 590.6314 & 4 & 40.7332 & 0 & 0.0000 \\
\hline$\geq 61$ & $63(0.34)$ & 0 & 0.0000 & 0 & 0.0000 & 0 & 0.0000 \\
\hline \multicolumn{8}{|l|}{ Reason for travel } \\
\hline Labor Worker & $16,074(86.91)$ & 392 & 243.8721 & 56 & 34.8389 & 32 & 19.9079 \\
\hline Business Trip & $1354(7.32)$ & 57 & 420.9749 & 1 & 7.3855 & 0 & 0.0000 \\
\hline Student & $473(2.56)$ & 3 & 63.4249 & 0 & 0.0000 & 0 & 0.0000 \\
\hline Traveler & $48(0.26)$ & 0 & 0.0000 & 0 & 0.0000 & 0 & 0.0000 \\
\hline Marriage & $544(2.94)$ & 14 & 257.3529 & 0 & 0.0000 & 1 & 18.3824 \\
\hline Others & $1(0.01)$ & 0 & 0.0000 & 0 & 0.0000 & 0 & 0.0000 \\
\hline \multicolumn{8}{|l|}{ Year } \\
\hline 2015 & $5117(27.67)$ & 89 & 173.9300 & 13 & 25.4055 & 6 & 11.7256 \\
\hline 2016 & $6657(35.60)$ & 255 & 383.0554 & 17 & 25.5370 & 8 & 12.0174 \\
\hline 2017 & $6720(36.34)$ & 122 & 181.5476 & 27 & 40.5588 & 19 & 28.2738 \\
\hline
\end{tabular}

epidemiology of some infectious diseases in DPRK and raising public health awareness about the potential risk of imported infections.

In this study, we found that both case numbers and incidence of TB and Syphilis infection had increased over time among North Korean travelers arriving in mainland China. Even though the incidence of HBV active infection in North Korean travelers was still much higher than Chinese national level, both case numbers and incidence of HBV infection in North Korean nationals decreased from 2016 to 2017. Incidence of HBV active infection increased with age while number of HBV negative case decreased with age. We also noticed a high percentage of HBV immunization in North Korean children which may be a result of the national HBV vaccination program applied in North Korea. In recent years, with the help of international medical aid, DPRK has started to vaccinate newborns against $\mathrm{HBV}$ nationwide and 7 million children were vaccinated against HBV from 2010 to 2012 with a coverage of $99.23 \%$ [5]. We also found that older North Koreans had relatively high HBV immunization rate, the reason for this phenomenon may

Table 2 HBV infection status in North Korean travelers

\begin{tabular}{|c|c|c|c|c|c|c|c|c|}
\hline \multirow{2}{*}{$\begin{array}{l}\text { Age } \\
\text { (year) }\end{array}$} & \multicolumn{2}{|c|}{ HBV immunization } & \multicolumn{2}{|c|}{ HBV active infection } & \multicolumn{2}{|c|}{ HBV past infection } & \multicolumn{2}{|c|}{ HBV negative } \\
\hline & $(\mathrm{N})$ & (\%) & $(\mathrm{N})$ & $(\%)$ & $(\mathrm{N})$ & $(\%)$ & $(\mathrm{N})$ & $(\%)$ \\
\hline $0-10$ & 7 & 46.67 & 0 & 0.00 & 0 & 0.00 & 8 & 53.33 \\
\hline $11-20$ & 16 & 0.54 & 18 & 0.61 & 4 & 0.13 & 2899 & 98.71 \\
\hline $21-30$ & 51 & 0.54 & 195 & 2.07 & 15 & 0.16 & 9175 & 97.23 \\
\hline $31-40$ & 3 & 0.12 & 94 & 3.52 & 14 & 0.52 & 2563 & 95.85 \\
\hline $41-50$ & 15 & 0.63 & 101 & 4.23 & 22 & 0.92 & 2249 & 94.22 \\
\hline $51-60$ & 17 & 1.73 & 58 & 5.91 & 9 & 0.92 & 898 & 91.44 \\
\hline $61-70$ & 3 & 4.84 & 0 & 0.00 & 4 & 6.45 & 55 & 88.71 \\
\hline
\end{tabular}


Table 3 Syphilis infection status in North Korean travelers

\begin{tabular}{|c|c|c|c|c|c|c|c|c|c|c|c|c|}
\hline \multirow{3}{*}{$\begin{array}{l}\text { Age } \\
\text { (year) }\end{array}$} & \multicolumn{4}{|c|}{ Overall } & \multicolumn{4}{|c|}{ Past syphilis } & \multicolumn{4}{|c|}{ Current active syphilis } \\
\hline & \multicolumn{2}{|l|}{ Male } & \multicolumn{2}{|c|}{ Female } & \multicolumn{2}{|c|}{ Male } & \multicolumn{2}{|c|}{ Female } & \multicolumn{2}{|c|}{ Male } & \multicolumn{2}{|c|}{ Female } \\
\hline & $(\mathrm{N})$ & (\%) & $(\mathrm{N}$ & $(\%)$ & $(\mathrm{N})$ & $(1 / 10,000)$ & $(\mathrm{N})$ & $(1 / 10,000)$ & $(\mathrm{N})$ & $(1 / 10,000)$ & $(\mathrm{N})$ & $(1 / 10,000)$ \\
\hline $0-10$ & 9 & 60.00 & 6 & 40.00 & 0 & 0.0000 & 0 & 0.0000 & 0 & 0.0000 & 0 & 0.0000 \\
\hline $11-20$ & 611 & 20.80 & 2326 & 70.20 & 0 & 0.0000 & 0 & 0.0000 & 0 & 0.0000 & 1 & 4.2992 \\
\hline $21-30$ & 1011 & 10.71 & 8425 & 89.29 & 0 & 0.0000 & 3 & 3.5068 & 6 & 59.3472 & 23 & 27.2997 \\
\hline $31-40$ & 643 & 24.05 & 2031 & 75.95 & 2 & 31.1042 & 10 & 49.2368 & 7 & 108.8647 & 13 & 64.0079 \\
\hline $41-50$ & 1561 & 65.40 & 826 & 34.60 & 5 & 32.0307 & 12 & 145.2785 & 2 & 12.8123 & 5 & 60.5327 \\
\hline
\end{tabular}

be that most older travelers are financially well off and have more access to medical resources.

Sexually transmitted disease (STD) is a taboo subject in DPRK. Up until now, there is no data available regards the prevalence of syphilis in DPRK. However, increasing numbers of syphilis case in our study suggest there is a possible high prevalence of syphilis in North Korea. Most syphilis cases were female aged 30-50, we have little knowledge about their sex life, but given the fact that they live in closed social circle, the chance of transmitting syphilis to local Chinese resident is small. No syphilis case was found in North Korean marriage-migrants, which may be a result of the pre-marriage medical screen for couples. In order to better understand the situation of syphilis in North Korean travelers, Dandong Customs will carry out education programs about STD in port areas and offer sanitary supplies and condoms to migrant workers for free.

Socioeconomic factors may account for the uneven distribution of TB cases in different travel groups. North Korean business men and oversea students are often better off economically than labor workers. Most TB cases found in this study were labor workers and not a single TB case was found in business or student group. The number of TB cases in North Korean labor workers found at Dandong port kept increasing for the last 3 years. The majority of North Korean workers in Dandong city are young female working in factories. Those migrant female workers always travel in group with one or two supervisors around and rarely talk to strangers. The living condition for those workers in China is generally poor with only few exceptions for those who work at fancy restaurants. All TB cases in this study were found in female workers in cloth factories, and not a single case was found in those who work at restaurants. Workers in restaurant are mostly come from wealthy families in North Korean and have received better education with better living condition than those who works at factories. All North Korean travelers with active TB infection were sent back to DPRK right after the diagnosis which left us little time to perform more medical test or offer proper treatment.
Up until now, North Korea has never reported a single case of local P.falciparum malaria infection. However, imported malaria of export laborers from Africa will increase the chance of local transmission of P.falciparum in North Korea. We have also noticed that the average age of North Korean travelers with infectious diseases were getting younger, especially in case of TB infection. Labor workers are the main source of entry North Korean travelers at Dandong port, and have the highest incidence of TB infection.

\section{Conclusion}

Our findings suggest that North Korean travelers,who enter China through Dandong port,have high incidence of TB, HBV and syphilis infection. Active surveillance at China-DPRK port can help with timely diagnosis of travelers with infectious diseases to prevent or at least postpone imported local transmission. In addition to entry surveillance, collaborations between China and international world are needed to help DPRK with their health related issues. We are looking forward to establish a fast and efficient way of sharing infectious diseases outbreak news with DPRK and conduct epidemiology field survey in the future. We are also reaching out for international cooperation to assist DPRK in setting up medical training programs.

\section{Abbreviations}

CDC: Central Disease Control; CIQ: China Inspection and Quarantine Bureau; DPRK: Democratic People's Republic of Korea; ITHC: International Travel Healthcare Center; TB: Tuberculosis; WHO: World Health Organization

\section{Acknowledgements \\ I would like to extend my sincere gratitude to my supervisor, Sun DX, for his instructive advice and useful suggestions on my thesis. Special thanks should go to my wife Zheng Huifang, who has put considerable time and effort into the comments on this draft.}

\section{Funding}

No funding

\section{Availability of data and materials}

The datasets generated and analyzed during the current study are not publicly available due to the fact that it contains personal information, but are available from the corresponding author on reasonable request. 


\section{Authors' contributions}

$\mathrm{P}-\mathrm{YH}, \mathrm{Y}-\mathrm{XT}$, and D-XS designed the study; X-XB and J-GL collected data; $\mathrm{P}$-YH performed the statistical analyses and outcome assessments, and wrote the paper. Y-XT, X-XB, J-GL and D-XS also contributed to the statistical analyses and the outcome assessments. All authors read and approved the final manuscript

\section{Ethics approval and consent to participate}

Because this study constituted public health surveillance rather than research in human beings, ethical approval from institutional review boards was waived by the ethic committee of Dandong International Travel Healthcare Center. Data collected from participants in this study are required by WHO's International Health Regulations and the Frontier Health and Quarantine Law of China, consent to participate was not needed $[16,17]$.

\section{Consent for publication}

Not applicable.

\section{Competing interests}

The authors declare that they have no competing interests.

\section{Publisher's Note}

Springer Nature remains neutral with regard to jurisdictional claims in published maps and institutional affiliations.

\section{Author details}

'Department of Infectious Diseases, Bethune International Peace Hospital, NO.398, Zhongshanxi Road, Shijiazhuang, Hebei Prov 050082, People's Republic of China. ${ }^{2}$ Dandong Customs, Dandong, China. ${ }^{3}$ Dadonggang Customs, Donggang, China. ${ }^{4}$ Dandong International Travel Healthcare Center, Dandong, China.

Received: 21 May 2018 Accepted: 27 December 2018

Published online: 05 January 2019

\section{References}

1. Seung KJ, Linton SW. The growing problem of multidrug-resistant tuberculosis in North Korea. PLoS Med. 2013;10(7):e1001486.

2. Unnewehr M, Stich A. Fighting hepatitis B in North Korea: feasibility of a bimodal prevention strategy. J Korean Med Sci. 2015;30(11):1584-8.

3. WHO. HIV/AIDS in the South-East Asia Region:Progress Report [cited 201711th November]; avalible from,http://www.who.int/hiv/pub/progress_ report2011/en/; 2011.

4. Seung KJ, Franke M, Linton SW. Multidrug-resistant tuberculosis treatment in North Korea: is scale-up possible? PLoS Med. 2016;13(8):e1002062.

5. Lee $\mathrm{YH}$, et al. Overview of the burden of diseases in North Korea. J Prev Med Public Health. 2013:46(3):111-7.

6. Lee $\mathrm{YH}$, et al. North Korean refugee health in South Korea (NORNS) study: study design and methods. BMC Public Health. 2012;12:172

7. Nebbia G, Peppa D, Maini M. Hepatitis B infection: current concepts and future challenges. QJM. 2012;105(2):109-13.

8. Seung KJ, Linton SW. The growing problem of multidrug-resistant tuberculosis in North Korea. PLoS Med. 2013:10(7).

9. Lee $\mathrm{H}$, et al. The role of major donors in health aid to the Democratic People's Republic of Korea. J Prev Med Public Health. 2013:46(3):118-26.

10. WHO. Bending the curve: ending TB [cited 201711th November]; available from http://apps.who.int/iris/bitstream/10665/254762/1/978929022584-eng. pdf?ua=1;2017.

11. WHO.The work of WHO in the Soth-east Asian[cited 201711th November]. avalible from, http://www.searo.who.int/mediacentre/events/governance/rc/ 70/sea-rc70-2.pdf?ua $=1 \& u a=1 ; 2016$

12. Park JW, Jun G, Yeom JS. Plasmodium vivax malaria: status in the Republic of Korea following reemergence. Korean J Parasitol. 2009;47(Suppl):S39-50

13. Zin T, et al. Influencing factors for household water quality improvement in reducing diarrhoea in resource-limited areas. WHO South East Asia J Public Health. 2013;2(1):6-11.

14. Lee $\mathrm{H}$, et al. The role of major donors in health aid to the Democratic People's Republic of Korea. Journal of Preventive Medicine \& Public Health. 2013;46(3):118-26
15. Yoo DH, et al. Mosquito species composition and plasmodium vivax infection rates for Korean army bases near the demilitarized zone in the Republic of Korea, 2011. Am J Trop Med Hyg. 2013;88(1):24-8.

16. WHO. Int Health regulations (2005), 3rd edn. http://www.who.int/ihr/ publications/9789241580496/en/ (Accessed 17 Feb 2018).

17. The State Council of the People's Republic of China. Rules for the Implementation of Frontier Health and Quarantine Law of thePeople's Republic of China, 2016. http://www.gov.cn/gongbao/content/2016/ content 5139369.htm (Accessed 17 Feb 2018) (in Mandarin).

\section{Ready to submit your research? Choose BMC and benefit from:}

- fast, convenient online submission

- thorough peer review by experienced researchers in your field

- rapid publication on acceptance

- support for research data, including large and complex data types

- gold Open Access which fosters wider collaboration and increased citations

- maximum visibility for your research: over $100 \mathrm{M}$ website views per year

At BMC, research is always in progress.

Learn more biomedcentral.com/submissions 